\title{
Navigating Hyperrealities : Tamil Film (Kollywood) Choreography as Screen Dance
}

Sandhiya Kalyanasundaram

\begin{abstract}
This essay discusses the choreographic ethos that integrates technology and dance as an evolving mode of storytelling in South Indian (Tamil-Kollywood) movies by tracing the work of director Shankar Shanmugam. Through analyses of song-dance sequences, I identify three key principles for using screendance techniques, and reflect on how these innovations contribute to cultivating and shaping the audience imagination. The audience is challenged to further engage at multiple levels and grapple with the relationships between human and more than human worlds. In the Kollywood scene, there is a constant quest for new techniques that can embrace inner realities.
\end{abstract}

Keywords: Hyperreal time-space, Kollywood screendance, embodied technology, Indian narratology, perception

Before him, a film mounted on a huge scale would be described as being "like a Hollywood movie."Now, we just say it looks... like a Shankar movie - Baradwaj Rangan'

Through this essay I am interested in outlining the specific Tamil film ethos that is rapidly evolving its storytelling modes in response to 1 ) a fast-changing social identity developed as a result of the changing Indian political, ecological and social landscape; 2 ) critical discourses about the individual and their role in society and the portrayal of the female characters; 3 ) what it means to be human in a world of technology and consumerism; 4) questioning the role of cinema and cinema artists in contributing to a dialogue about living our anthropocentric lives whilst beginning to inquire empathetically into more-than-human worlds; 5) bridging the quest of the artists and the audiences alike.

In India, particularly in South India, one of the leading performing arts companies, Attakkalari ${ }^{2}$ based in Bangalore have experimented with videodance and/or screendance in several formats including mixed media. In films however, the particular aesthetic of mixed choreography that borrows from world dance as well as specific Indian classical and folk forms, has generally led to applying the idea of videodance to dance made for the screen and including video, digital media, vfx/cgi effects and complex character costuming with prosthetics or large-scale festival celebrations. The camera does not take center-stage in most South Indian film choreography, serving merely the role of documentation or recording purposes, however in the case of the films of South Indian Director Shankar Shanmugam, there is an attempt to reprise, recreate or 
enrich some of the current debates in film-making across the world through camera techniques, as well as improved sound design, editing and costume design.

As an extension of these developments, innovations in film choreography techniques are a standout feature in Shankar's films. Since the early nineties, choreography in many of the songs from his movies includes graphics, and dancers responding to a graphic character, use of motion capture technology and filming 'timeslice' by linking multiple cameras.

I'm tempted to call Shankar Tamil cinema's first real 'social' spectacle director, someone who makes stories set in ourage, in our neighbourhoods, in our physical world (Enthiran being an exception, of course), addressing our problems, but with the pomp and pageantry of Indra's realm or Shiva's abode or the Arabian Nights ${ }^{3}$

writes Baradwaj Rangan, 2018, noted film critic and historian as he reviews Shankar's Tamil films from the nineties. This paper reflects on four songs that attempt to adapt the hybrid elements of screendance into Tamil film choreography through the films directed by Shankar from 2005 to 2018.

Songs in Tamil films are typically released a few months ahead of the film and serve to create anticipation through repeat screening on television or releasing lyric videos on YouTube: audiences have personal favourites before they watch the movie on screen. Music lovers repeat their viewing of movies just for the song sequences in the movie as well. Songs typically have their own narrative complementing the narrative of the movie but not necessarily following the sequence of the movie. Song and dance sequences serve to highlight a character's journey, a unique life experience that fundamentally changed their perspective or important nuances that cannot be captured through the mainstream narrative of the film.

Songs and their accompanying dance choreographies are effective on many levels within a specific film; they can provide significant moments of interruption in the narrative, or simply advance the narrative; they may interpret a hidden story-line or can allow a permissible expression of romance that may in other ways be inexpressible. Often they create an imagined fantasy space, intensifying the emotional content of the story and offering suggestions of eroticism. ${ }^{4}$

To outline the power and impact of the early release of songs, I describe the fan response to the song "Arima Arima" from the movie Enthiran (The Robot):

The early evening light softly merges into a rapturous October twilight as 50 men and women, most of them novice dancers, line up neatly with printed masks of the Robotic 'Chitti' over their faces and dance to the song, "Arima arima." This was 2010, San Jose California, the first day of the release of the movie Enthiran, starring celluloid god, Rajnikanth and directed by Shankar Shanmugam known for his futuristic imagination and big budget movies using a variety of visual effects and technology. All the dancers were fans of Rajnikanth and they had learnt the choreography for the song in the time period between song release and movie release. Dancing this prior to the screening of the movie in front of the theatre was their tribute to a 
much awaited film of their beloved superstar before they walked in to watch the movie. Local media and newspapers covered this fan dance which continues to be a hallmark feature of celebrating the release of a Rajinikanth movie by his fans.

In the movie Enthiran, actor Rajnikanth plays both a scientist and creator of the humanoid Chitti and Chitti itself. The song Arima Arima features Chitti, the robot. Chitti widely captured the hearts and minds of viewers of all ages beginning as a robot learning to understand human emotions, falling in love with a beautiful human woman, then gradually programmed as a destructive element only to be dismantled and displayed as a museum exhibit. The movie ends with the response by Chitti, "Naan sinthikka arambichen" (I started thinking) to a curious student's question of why the robot was dismantled.

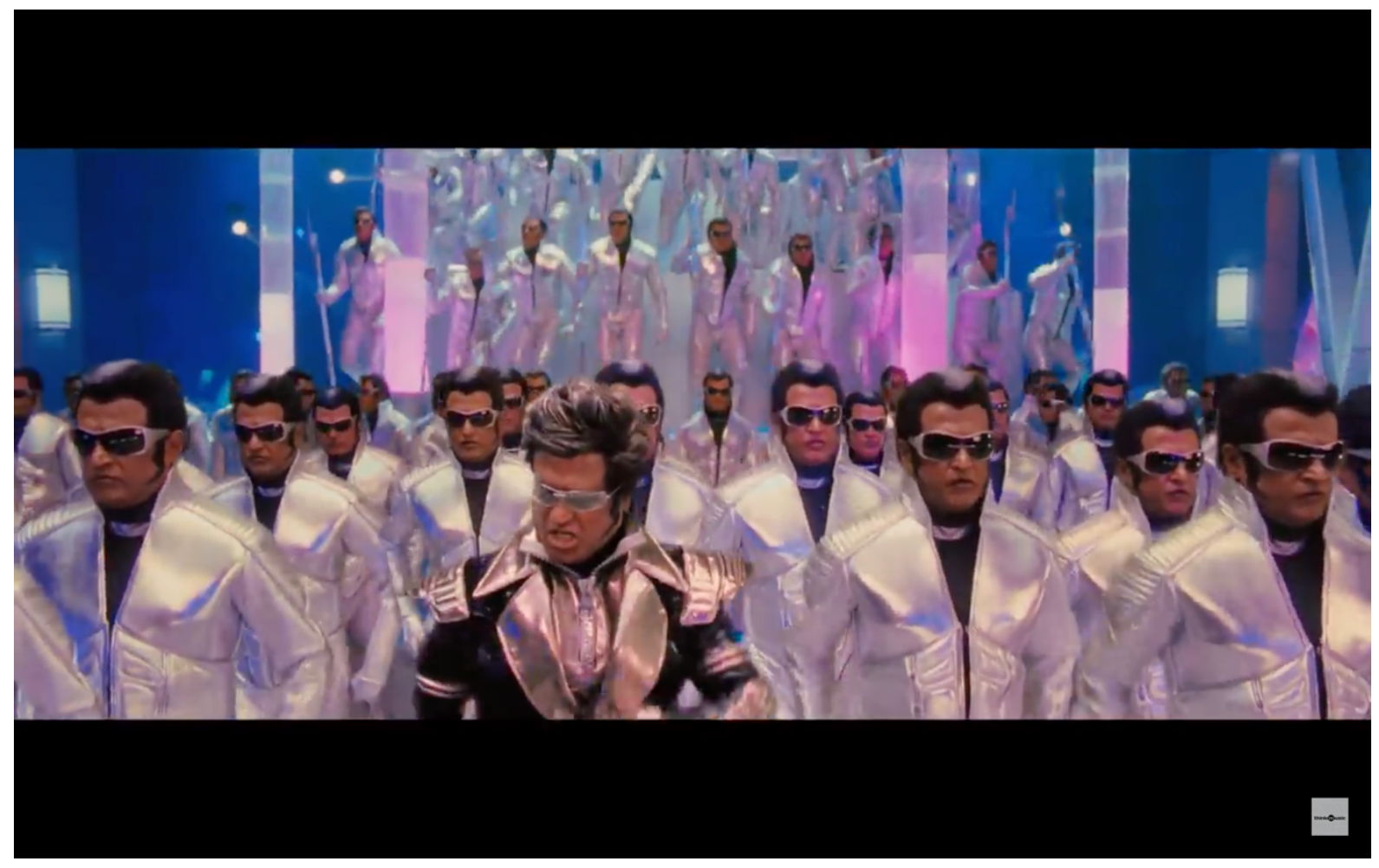

Still from Arima Arima. Screenshot by author ${ }^{5}$

Arima Arima, choreographed by Prabhu Deva, was filmed at Ramoji Rao Film City, Hyderabad, India. The song features the transformed humanoid Chitti smitten with a human woman, Sana, and his robotic army that is ready to destroy at his command. It clearly showcases the rise and power of Chitti from a service robot to one that is set to conquer and destroy. The song includes elaborate sets and costumes, vfx, choreographed camera movements and editing work, deciding where a movement may begin or end and includes several elements of screendance. The song plays with the idea of multiples without cloning a single individual. Instead, different dancers are placed alongside interacting as multiples bound by rhythmic patterns to express and highlight the complex interiority of Chitti. The bodies in the frame are choreographed as is the space around and the camera capturing all of this is choreographed as well, creating an 
expansive framework for the audience to delve into the robotic and power-hungry Chitti's mindscape. It seems like his robotic army is completely an extension of him and towards the end of the song the multitudes of Aishwarya Rai dancing before his eyes, while the audience gets a glimpse of the words "battery low", all reflect Chitti's multiple failed attempts to gather a full understanding of the human psyche and its emotions. While the fan dance was just that - a tribute of the fans for their superstar - it was clear that their imaginations were sparked by the robotic character and the choreography using hybrid elements of screendance was powerful enough to elicit a major audience response even before the fans watched the movie.

Another song in the movie Enthiran using screendance elements is Irumbile oru Idhayam, choreographed by Remo D'Souza. ${ }^{6}$ The changing color tints in the song generally follow the color scheme steel gray, chrome, gold and black keeping in line with a robotic metallic lead and animatronics.
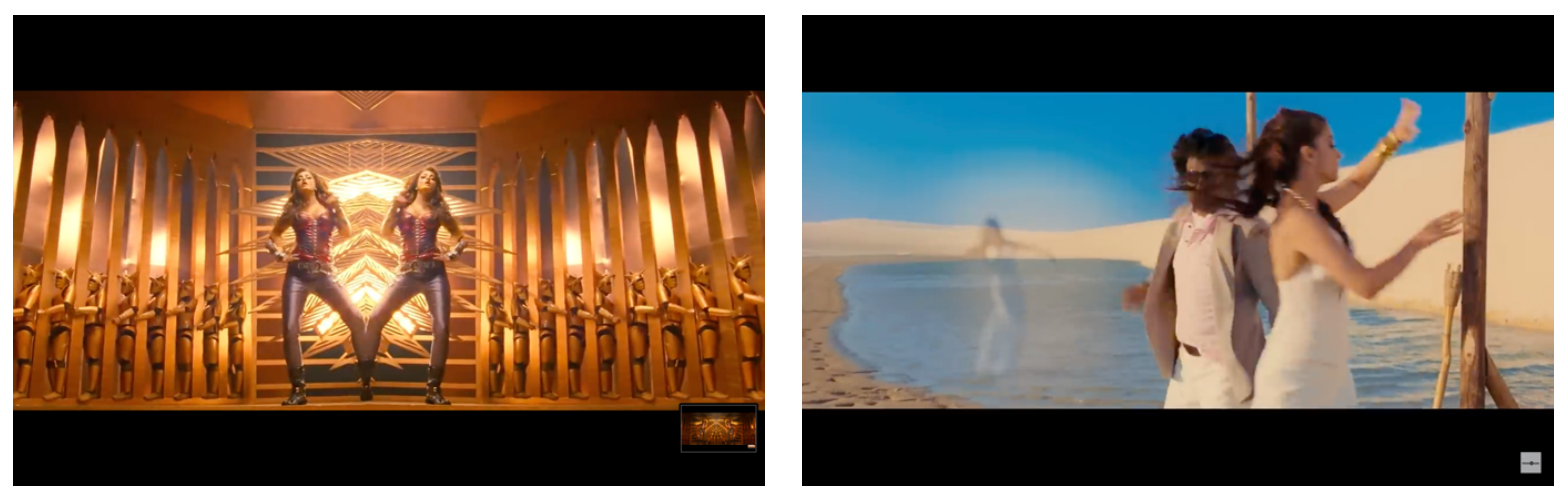

Stills from Irumbile oru Idhayam and Kaadhal Anukkal. Screenshots by author.

This song contrasts immensely with the movements and the color schemes used in the song for the scientist Rajinikanth, Kaadhal Anukkal, ${ }^{7}$ choreographed by Prabhu Deva. Here the bodies are positioned in a vast space with several wide-angle shots providing fresh perspectives to the audience about being human by connecting to the environment and placing the protagonists in a realistic location. The light happiness of the female dancer's heart is shown by showing her suspended in space while the next instant transforms her corporeal reality into butterflies that then flit away. Moments in the song show the path of her movement in space from position ' $a$ ' to position 'b' by transposing her at once in both positions. She remains in her colourful entirety in position ' $b$ ' while fading slowly into transparency position ' $a$ '. Her movements are choreographed from land into water as a shimmering mirage who has cast her lovely spell on the protagonist. The spatial play creates an intrigue for her character emphasizing a complex, playful and intelligent woman.

Douglas Rosenberg, $2012^{8}$ writes about screendance as,

In fact, the term might encompass any form of mediated dance delivered to any kind of screen. This could include animated dance on a computer screen, cine-dance on a projection screen or videodance projected on a wall or glass of milk. The term "screen" 
here is thus loosely applied to and open to interpretation: it implies something that is a receptor of an otherwise ephemeral image, and which reifies that image in the process of receiving it... Screendance alludes to the end point of a process in which dance is grafted to or merged with techniques of representation particular to viewing on a screen.

From the vantage point of this broad encompassing definition of screendance, Shankar's films are a harbinger of using the hybrid elements of (what we might read as) screendance in Kollywood choreography, as well a good case for adaptive use of the idea of screendance in Tamil films. Let us consider the song Irumbile oru idhayam as a standalone song and the impact of choreographing, through screendance, on the audience. The song starts out with Chitti surrounded by many robots each of whom seem to mirror each other and Chitti itself. Opening out into an endless mirroring, the choreography introduces the human Sana as Chitti's partner and it seems like there lies a palpable communication of the intangible between robot and human. Yet as the song progresses, the endless mirroring is collapsed into disappearing robotic selves that merge into edges, walls and the periphery, and the audience is invited into questions of imagination, metaphor and the interrogations of the mind-body at the interface of technology.

On one level a piece of pure entertainment, this song-dance can also provoke deeper questions: how should consciousness be defined? As a human being, what does the compass of morality mean? Could it be extended to a robot? If a robot can have the imagination of a song sequence with its love interest just as a typical Tamil movie song-dance sequence, should a robot be considered human? What does it mean to establish bridges between the nonhuman and the human world, through dance? As the audience grapples with these questions and a wealth of meanings emerge, Shankar's film plays powerfully with adapting the idea of screendance in South Indian Film choreography particularly through his Tamil films. The idea that the sum of the parts is not equal to the whole is recurrent in his song dance sequences.

Katrina McPherson notes in her $2006^{\circ}$ book, Making video dance- a step-by-step guide,

Through the use of different shots and angles, the camera can take the viewer to places they could not usually reach. The lens can enter the dancer's kinesphere - the personal space around them that moves with them as they dance - focusing on a detail of movement and allowing an intimacy that would be unattainable in a live performance context.

Choreography in Shankar's movies is a clear extension of his filmmaking, his script and direction where each sequence is elaborately matched to his imagination and conception of the characters, their lives within the story and their individual endpoints and outcomes. The choreographic feel of Enthiran continues to achieve Shankar's cinematic process - working with five different choreographers in a combination of styles, locations and perspectives.

Winding back in time to look at Shankar's 2005 movie, Anniyan (The Stranger), we find the use of screendance elements in the song Kannum Kannum Nokia. ${ }^{10}$ Anniyan is a psychological thriller centered around a protagonist having multiple personality disorder. 
Actor Vikram plays Ramanujam, an idealistic, law-abiding lawyer and his two other identities: a high-energy metrosexual fashion model Remo, and a 'savage', Anniyan. The song Kannum Kannum Nokia choreographed by Raju Sundaram is a love duet between the metrosexual Remo and his love interest Nandini (actress Sadha). Pictured amidst steel, glass and concrete (the location is a building by Japanese architect Kisho Kurokawa), the choreography uses, and extends, the reflection of light to play with materiality, giving to the audience an extra sense of curiosity and exploration by using obtuse camera angles, alternating between the 'real' and the 'unreal' and the multifaceted eight directions. Materiality, identity and choreography are completely fused in this song. The camera pans, tilts and tracks serving to defamiliarize the viewer creating a clear tension between the ambiguity of Remo's identity and individual existence allowing the viewer to traverse on an independent experience layered into the visual experience of the choreography. Within the context of the movie it positions Nandini's obsessive love for Remo only to realize that Remo is merely an identity.

In 2015, Shankar released the science fiction movie / which tells the story of a body builder turned supermodel, played by actor Vikram, who suffers by malicious injection of a virus, loses his career, recovers and eventually exacts revenge on the perpetrators. Aila Aila ${ }^{11}$ is a song in the movie which showcases the meteoric rise of the protagonist Lingesan (Vikram) alongside his co-star Diya (actress Amy Jackson) it is a compositional play on seven product advertisements popular between 2012 and 2014. While the song appears as a patchwork of commercials, the song captures a section of the journey of the protagonist from being a small time bodybuilder turned model to a successful model and actor. The protagonist Lingesan starts his career with boring commercials and is eventually noticed for his physique. He is paired with a beautiful model for several high-profile commercials. This launches his career as a very successful model and actor and the purpose of the song is to show his personal success as well as the success of the pair which leads to the actual plot of the movie. The song was choreographed by the duo Bosco Martis and Caesar Gonsalves and I mention it in this paper because it contrasts the other works discussed, through use of camera, choreography, costumes, set design and vfx elements.

This song successfully draws the viewer's eye from one set of shots to the next and also creates active-viewing opportunities for the viewer to recreate the rest of a sequence through suspense and humor. The montage approach to editing allows a completely different experience of time and space for the audience. The choreography is not a mere re-creation of the product commercials, it is instead an intelligent and humorous recreation of Tamil popular culture and the identity of the youth. 


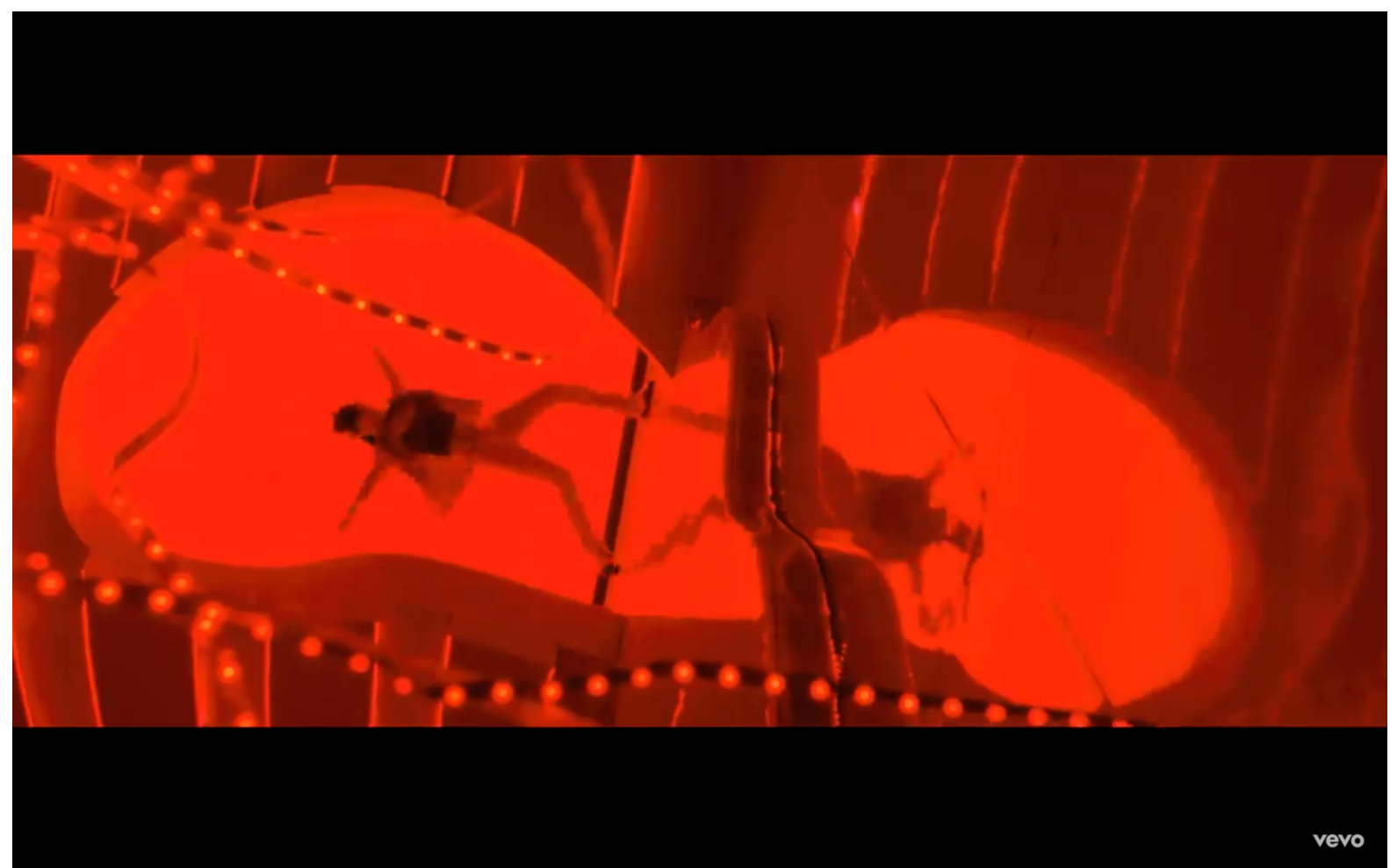

Still from Aila, Aila. Screenshot by author

Choreographer Bosco Martis, $2018^{12}$ says,

Knowing Shankar's large-than-life vision, I didn't mind giving him the time. He's a choreographer's delight because he gives a choreographer the vision and capacity to explore and that's the reason why I felt I should try and understand his style of filmmaking.

2018 featured the release of Enthiran's sequel 2.0 with Rajnikanth reprising his roles and actor Akshay Kumar playing Pakshirajan, the villain. In this movie, the song Raajali ${ }^{13}$ has primarily Vfx elements with elaborate costume design for Pakshirajan and Chitti, the humanoid. Pakshirajan is a metamorphosed, altered existence, bordering on radical non-identity. The song showcases the interaction between Chitti and Pakshirajan where Chitti has been reassembled to eliminate Pakshirajan. The song creates a fantasy world of electromagnetic radiation, millions of cell phones, aural bodies and robotics and multiple choreographed camera angles. In this context Susan Kozel's words usher in the right focus,

"Implicit is an inability to tell where the digital body ends and the physical body begins, and, most important, the conviction that distinguishing the two no longer matters". ${ }^{14}$ Choreography for Pakshirajan's movements evoke a large bird of prey possibly from another geological time, violent in nature yet threatened and frightened of an unknown impending apocalypse. The audience enters Deleuze's notion of affect, which is "not the passage from one lived state to another but man's nonhuman becoming"1516. While good triumphs over evil in a technological fantasy, environmental damage and the cost of human excesses on the morethan-human world is the epiphany. 

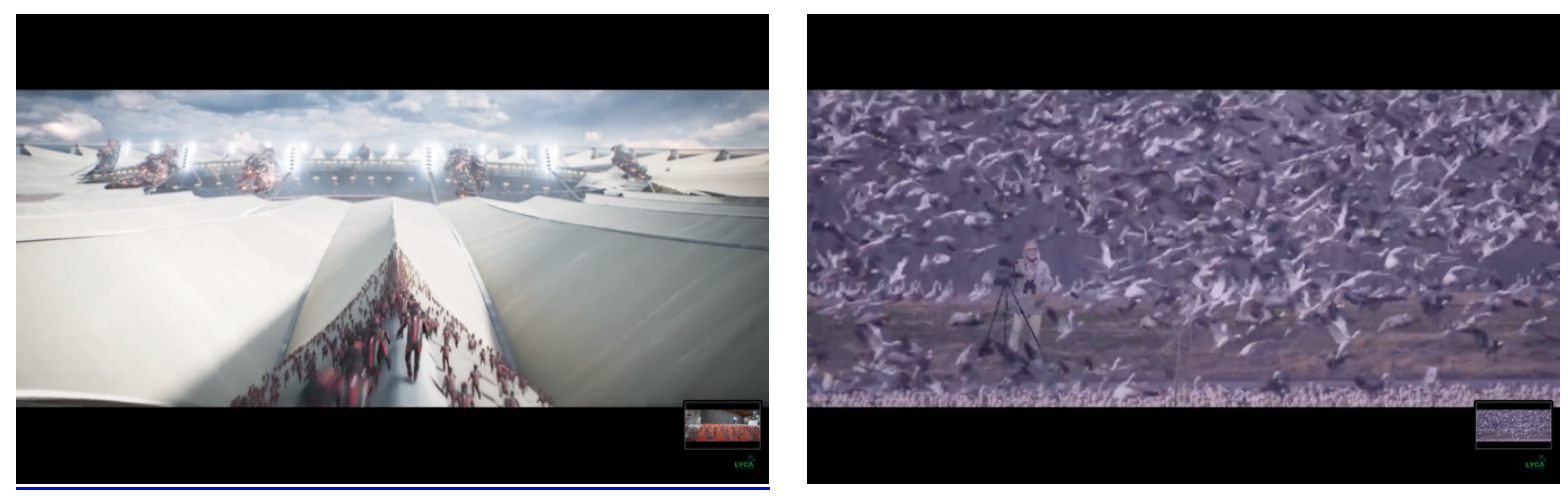

Stills from Raajali (left); Pullinangal(right). Screenshots by author

Raajali offers yet another layer of contemplation when contrasted with the song, Pullinanga/ ${ }^{17}$ in a revealing flashback about Pakshirajan's past where he is originally an ornithologist. We see this idea of contrast between two songs within a film used to elaborate and expand unspoken sociological and ethical questions for the audience. The audience is drawn into the life of birds in through bird movements, feeding, flocking and flight patterns from different locations and timepoints merged with choreographic editing. What the audience perceives through the Pullinanga/song therefore is a fluidity of movement, a dancescape of evolutionary order, where it is possible to be imaginatively transported into more-than-human ${ }^{18}$ perspectives. Placed in contrast, the songs Raajali"and Pullinanga/from the film 2.0 provide opportunities for crossspecies empathy. David Abram ${ }^{19}$ writes evocatively in 'Becoming Animal',

When we disparage the intelligence of birds, or the size of their brains, we miss that flight itself is a kind of thinking, a gliding within the mind, a grace we humans rarely attain in our contemplation (although if we're following a falcon with our focus, we sometimes find our thoughts soaring as well).

Pakshirajan seems to play on this thought. We are never far from the bird's intelligence or its appreciation by the human in the new fused identity of Pakshirajan. Pakshirajan does not show the elation and joy of flying in his own body for his role here is as guardian and savior, avenger of the birds. However, in the tension and kinetic conversation emanating from his presence, he raises our perception of this hybrid man-bird world, pushing us to move seamlessly between bird-thought and human-thought. The question for a mature audience however is not just empathy, we, like Timothy Clark (2015) must question the limits of fiction and wonder if literary narrative is actually "allied with forms of anthropocentric thinking."

Following Rosenberg in his book, Screendance: Inscribing the Ephemeral Image,

In screendance terminology and semantics have evolved in a way that is perhaps quite accidental, often a case of one community picking up the vernacular usage of a term or 
phrase and institutionalizing it over the course of a number of iterations, to be adopted by another community of like-minded practitioners. ${ }^{20}$

we find that within the Tamil film community, purposes for using screendance elements in film dance choreography seem to converge on one or more of the three key principles:

\section{1) Time and Space}

There is usually a direct correlation between the physical passage of time and space. The ability to travel mentally through time as past present and future is a defining characteristic of consciousness of being human. Cassanto and Boroditsky $2008^{21}$ have suggested "that our mental representations of things we can never see or touch may be built, in part, out of representations of physical experiences in perception and action". Recent research has also shown that mental time travel has a spatial counterpart and there is an association of physical movements through space (Miles et al., 2010a22; Miles et al., 2010b ${ }^{23}$ ).

Choreography for song-dance sequences in director Shankar's Tamil films plays on the idea of this mental time travel and altering perception and reality by distorting time and space. The temporality resident within the choreographic process when converted on screen allows for a hybridization of the real and the fictional in the audience's perception. There is a certain quality of vulnerability to the space that is created onscreen- it is real yet unreal because it is revelatory of the interior space. Time-space in Tamil film song dance generally works on multiple layers of audience perception. Since the protagonists in Shankar's films tend to be complex characters which traverse multiple identities and ethical beliefs, there is an expectation from the audience to simultaneously comprehend very different interior time-spaces within the same protagonist. In all the song-dance sequences described, there is a clear juxtaposition of images/shots that are intended to evoke associations through memory in the audience's minds, that is not merely a causal chain of linear unfolding story elements.

\section{2) Narrative}

Tejaswini Ganti ${ }^{24}$ writes, "Bollywood movies are aesthetically and culturally distinct from Hollywood but as prolific and ubiquitous in its production and circulation of narratives and images." While writing about Bollywood film music in 2001, Nasreen Munni Kabir ${ }^{25}$ notes, "It is mainly the music that shows fantastic new energy and originality." Jonathan Durr ${ }^{26}$ in his thesis describing the performance sequence says, " it is here that innovations in technology, allusions to socio-political realities, and aesthetic experimentation are most in evidence."

Shankar's narrative is mythical and futuristic all at once. Shankar's films continue to build within the Indian narratology devices. Ayyappa Paniker" lists these as "Interiorisation, Serialisation, Fantasisation, Cyclicalisation, Allegorisation, Anonymisation, Elasticisation of time, Spatialisation, Stylisation, Improvisation." Therefore Shankar manages to emerge a successful hybrid space for creative expression. Song-dance sequences in many of Shankar's movies take symbolic elements of myth and project, juxtapose and transmute onto the futuristic. Narrative in Shankar's song- dance sequences have a tendency to comfortably move between the real 
and the surreal and technology enables creating the narrative superstructure. Ayyappa Paniker ${ }^{28}$ notes that

...some of these are a regular feature of postmodern fiction in the West. Traditional Indian techniques have surfaced in experimental Western theatre during the past century, and more or less in the same way, narrative devices common in traditional Indian texts have materialised in modern and post-modern European fiction.

Shankar's films provide a crucial interface between the traditional narrative structures and modern technological tools to allow the audience to seamlessly move between imagination and reality. Anniyan's Remo is one identity of multiple personality disorder. Using fragmented elements of screendance, Shankar manages to create an alternative space where the audience can reside comfortably and enjoy the love duet yet at the back of their minds feel queasy about the almost unreal existence of Remo within the context of the larger narrative of the film. In both films, Enthiran and 2.0, there exist two parallel worlds: one of the humanoid robot and the other human. In the song-dance sequences of both films, emotions, events and materiality coalesce between the human and humanoid worlds into hyperreality.

\section{3) Technology as Embodiment}

Technology becomes a key tool that aids as well as constructs Shankar's film narrative. Baradwaj Rangan ${ }^{29}$ says, "That's Shankar for you. Someone who's always out to wow you. Someone whose imagination has always exceeded what the practical realities of Indian budgets and effects houses can give him - but also someone who doesn't let this stop him." In Shankar's storytelling, nothing is left to chance and the worldview of the characters is made visible to the audience using techniques of sensorial heightening through technology. We, as audience enjoy the need to slip between realities and the opportunities to embody technological space while watching his movies. Susan Kozel in her book Closerobserves,

Wearables are worn close to the body because we want them to be there; we invite them to be there and to share our personal space with fluid and transforming expectations. It is here that they rub shoulders with domains of body modification and prosthetics: techniques and technologies of the body, from martial arts to robotic arms, outline and amplify the metaphysical structure of our flesh. ${ }^{30}$

In Shankar's movies, body modification using prosthetics is a common and recurring feature. Very much in line with Susan Kozel's description above, Pakshirajan and Chitti's prosthetic makeup from the movies Enthiran and 2.0 allows for creating their metaphysical identities. A perfect illustration from the movie 2.0 shows Pakshirajan constructing a new 'negative' body composed of millions of cell phones that are powered by a concentrated mass of negative charge with electromagnetic properties and destroying telecommunications towers as a retribution for avian deaths. The public is terrified and normal functioning is disrupted. This negative body was created with extensive prosthetic make up of the actor. ${ }^{31}$ 
Within Shankar's song-dance sequences, the moving images and other sensory material that we are presented with make our encounters into the ephemeral kinaesthetic plausible enabling empathy and a connected hyperreality that we can come back again to revisit, learn from and embody within ourselves.

Shankar's fims feature male protagonists with dominant paradigms of patriarchal masculinity containing shades of mythical heroism. While young males rejoice in this celluloid version of hypermasculinity, the reality of their lives is challenged by a postmodern view which questions these male identities and their power. There is in Tamilnadu, as in other parts of the world, a cultural shift away from the hegemonic masculinity. Shankar's films bring into focus the metrosexual man as a transitional option for young men to relate with. This transitional comfort is particularly emphasized in the songs from Shankar's movies that allow the young male to morph into a 'desirable male' in touch with a feminine aspect, care about appearance and spend money for luxury as opposed to saving for a distant future. Through the song and dance sequences young men reimagine their identities as well as social mobility and allow themselves to express emotion. The song and dance sequences in Shankar's movies highlight this exclusive fantasy and relief for the modern young man faced with cultural and individual performative anxieties.

From an audience perspective, Shankar's refusal to be limited by traditional shooting locations, budgets and his desire to play with technology allows reconceptions of reality because of our connectedness through technology. Geographer Nigel Thrift's perspective seems to echo this reconception as he says,

It could be argued that the human body is what it is because of its unparalleled ability to co-evolve with things, taking them in and adding them to different parts of the biological body to produce something which, if we could see it, would resemble a constantly evolving distribution of hybrids with different reaches. ... The human body is a toolbeing. ${ }^{32}$

Films hold a wild imagination for Indian audiences. Dance and choreography from films move into reality TV shows, street dances, stage shows, mushrooming dance schools, performances at family events and in several other contexts. More and more young dancers are training their bodies to find that ductile, malleable extension of themselves found in the imaginative technology extended by the films they love. Gopal and Moorti note that,

Choreographed sequences often migrate from the screen to the stage, to dance halls, and to community centers. These migrations not only draw on but also radically recode the meanings that the dance had in its filmic context. ${ }^{33}$

Individuals take on, for the sheer pleasure of re-finding, and re-modelling in their own bodies, the complex characters of film protagonists, re-shaping them into new identities. A perpetuating cycle of myth, screen and body finds its way into public imagination. Shankar's films nudge the audience towards staying alert about social issues of poverty, inequality and corruption. While staying within the boundaries of popular Tamil culture, his films offer a 
window to look at the pressures on, in particular, young men in urban Tamilnadu and their attempts to negotiate globalisation and modernity, within the framework of traditional values.

\section{Author Biography}

Sandhiya Kalyanasundaram is a dance educator, choreographer and poet. Trained in Bharatanatyam, Butoh and Flamenco, Sandhiya has led and performed in several collaborative performances between dance styles, served on the Jury Panel for the San Francisco Ethnic Dance Festival and used dance therapy to work with survivors of domestic violence. She enjoys working at the intersection of science and art and is currently expanding her research into the role of dance in science education. Sandhiya partners with local communities to develop sustainable foodscaping and urban restoration. Before her work with the environment, she was a researcher in the field of Neuroscience.

\section{References}

Abram, David. Becoming animal: an earthly cosmology. New York: Pantheon Books, 2010.

Abram, David. The spell of the sensuous: perception and language in a more-than-human world. New York: Random House, 1997.

Baradwaj, Rangan. "Every Shankar film, ranked." Posted November 22, 2018

https://www.filmcompanion.in/every-shankar-film-ranked-baradwaj-rangan-2.0-enthiran-arrahman-rajinikanthmudhalvan-indian/

Casasanto, Daniel, Boroditsky, Lera. "Time in the mind: Using space to think about time." Cognition 106 (2008): 579-593 https://doi.org/10.1016/j.cognition.2007.03.004

Clark, Timothy. Ecocriticism on the Edge: The Anthropocene as a Threshold Concept. London: Bloomsbury 2015: 187.

David, A. 2015. "King of Bollywood? The construction of a global image in Shah Rukh Khan's dance choreography." Shah Rukh Khan and Global Bollywood, Eds. R. Dudrah, E. Mader \& B. Fuchs Oxford University press, 2015. Retrieved 3/22/2019.

https://www.academia.edu/17555981/King of Bollywood The construction of a global image in Shah Ruk h Khan s dance choreography

Deleuze, Gilles, Guattari, Félix, Tomlinson, Hugh and Burchell, Graham. What Is Philosophy?London: Verso, 1994: 173

Durr, Jonathan. "Seeing Song in Bollywood: Landscape, the Postnational and the Song-and-Dance Sequence in Hindi Popular Cinema" (Master's thesis), University of Wisconsin, Madison. 2001: 36

Ganti, Tejaswini. Bollywood: A Guidebook to Popular Hindi Cinema. New York, NY: Routledge, 2010:2

Gopal, Sangita and Sujata Moorti. "Introduction." Bollywood- Travels of Hindi Song and Dance, Eds. S. Gopal and S. Moorti Minneapolis and London: University of Minnesota Press, 2008. 1-60. 
Kabir, Nasreen M. Bollywood: The Indian Cinema Story. London: Channel 4 Books, 2001: 130

Kozel, Susan. Closer: Performance, Technology, Phenomenology. Cambridge, Mass: MIT Press, $2007: 80$. https://doi.org/10.7551/mitpress/9780262113106.001.0001

McPherson, Katrina. Making Video dance. A step-by step guide. London and New York: Routledge, 2006.

Miles, Lynden K., Karpinska, Katarzyna, Lumsden, Joanne, and Macrae, Neil C. The Meandering Mind: Vection and Mental Time Travel. Plos One. 5 (5): e10825. https://doi.org/10.1371/journal.pone.0010825

Miles, Lynden K., Nind, Louise K. and Macrae, Neil C. 2010. "Moving through time". Psychological Science. 21 (2): 222-3. https://doi.org/10.1177/0956797609359333

Paniker, Ayyappa. 2003. Indian narratology. New Delhi: Indira Gandhi National Centre for the Arts: 4

Pudipeddi, Haricharan. "Bosco Martis on Rajinikanth's 2.0, choreographing Endhira Logathu Sundariye and why he likes working with Shankar." Posted November 19, 2018

https://www.firstpost.com/entertainment/bosco-martis-on-rajinikanths-2-0-choreographing-endhira-logathusundariye-and-why-he-likes-working-with-shankar-5578621.html

Rosenberg, Douglas. Screendance: Inscribing the Ephemeral Image. Oxford: Oxford University Press. $2012: 16$. https://doi.org/10.1093/acprof:oso/9780199772612.001.0001

Smith, Daniel and Protevi, John. "Gilles Deleuze" Updated Feb 14, 2018

https://plato.stanford.edu/entries/deleuze/ retrieved 4/1/2019

Thrift, Nigel. Non-representational theory: Space, politics, affect. London, UK: Routledge. 2008:10.

https://doi.org/10.4324/9780203946565

\section{Notes}

${ }^{1}$ Rangan

${ }^{2}$ http://www.attakkalari.org

${ }^{3}$ Rangan

${ }^{4}$ David

${ }^{5}$ https://www.youtube.com/watch?v=5F3H9 pYpYg

${ }^{6}$ https://m.youtube.com/watch?v=U7x8iEiax64

${ }^{7}$ https://www.youtube.com/watch?v=gpVA5mx73UE

${ }^{8}$ Rosenberg, 16

${ }^{9}$ McPherson, 24

${ }^{10}$ https://www.youtube.com/watch?v=gSnSo0DAJAE

${ }^{11}$ https://www.youtube.com/watch?v=i1 rYKmNS8uQ

${ }^{12}$ Martis

${ }^{13}$ https://m.youtube.com/watch?v=2268wHKStWI

${ }^{14}$ Kozel, 80

${ }^{15}$ Deleuze, 173

${ }^{16}$ Smith and Protevi

${ }^{17}$ https://www.youtube.com/watch?v=sNm55ptmDcs

${ }^{18}$ Abram,

${ }^{19}$ Abram,

${ }^{20}$ Rosenberg, 16

${ }^{21}$ Casasanto and Boroditsky

${ }^{22}$ Miles et al., (a) 
${ }^{23}$ Miles et al., (b)

${ }^{24}$ Ganti, 2

${ }^{25}$ Kabir, 130

${ }^{26}$ Durr, 36

${ }^{27}$ Paniker, 4

${ }^{28}$ Ibid., 4

${ }^{29}$ Rangan

${ }^{30}$ Kozel, 286

${ }^{31}$ https://www.legacyefx.com/avengers-infinity-war

32 Thrift, 10

${ }^{33}$ Gopal and Moorti, 32 